\title{
Die skepping as gelykenis: ' $n$ Beoordeling van die skeppingsleer van Karl Barth in die lig van die appèl van die ekologiese krisis
}

\section{J Buitendag}

\section{Abstract}

The creation as an analogy: An assessment of the doctrine of creation of Karl Barth in the light of the appeal of the ecological crisis.

In a comprehensive article in Afrikaans, the author points out that the problem of the relation between man and nature has become eminent as a result of the ecological crisis. The doctrine of creation as offered by Barth, does to a certain extent, present a coherence of being amongst creatures, but is nontheless not accepted. The main reason for this is that his ontological principle of covenant imputes a docetic character to the creation. This is ascribed to the fact that Barth operated with a canon behind the canon. The author concludes his article by outlining some distinctive features of a theologia naturae.

\section{INLEIDING}

\subsection{Die ekologiese krisis: Krisis en uitdaging}

Die skeppingsleer het sedert die afgelope paar dekades in die teologie 'n algehele klemverskuiwing ondergaan. In die verlede het dit eintlik maar gewentel om die spanning tussen 'n Bybelse wêreldbeeld soos ingelees in Genesis 1 en 2 en die moderne natuurwetenskaplike wêreldbeeld aan die ander kant. Hierdie spanning is hoofsaaklik indifferent of diametraal, tangensiaal of komplementêr beskou. Vandag word die skeppingsleer egter in terme van die magsprobleem van die natuurwetenskap, waarby die lewe van die mens ingereken word, gehanteer. Virtueel handel dit oor die ekologiese vraagstuk: naamlik hoe die teologie die nie-menslike kreatuur as skepping van God en as element van ons menswees verstaan en dit dan sodanig aan die wetenskap, die politiek, die industrie en die gemeenskap kommunikeer. 
Onder ekologie verstaan ons na aanleiding van die Griekse woord vir huis, die leer van die huishouding, oftewel van die omgewing. Dit het te doen met die komplekse struktuur van die wisselwerking tussen organisme en omgewing. Ons praat van 'n ekologiese balans wanneer die werking en teëwerking van enkelelemente deur 'n natuurlike reguleringspotensialiteit 'n relatiewe stabiliteit daarstel. ' $n$ Bepaalde ekosisteem ontstaan wanneer sekere enkelelemente vanweë soort en getal saamgroepeer en op grond van inherente kompensasievermoë 'n bepaalde ewewig bereik. Dit vorm die basis van alle biologiese voortbestaan. Die ekologiese krisis meld hom aan wanneer hierdie balans versteur word. Alhoewel nie noodwendig dadelik herkenbaar nie, ontstaan die ekologiese krisis as gevolg van voortdurende verandering en versteuring van die natuurlike bestaansvoorwaardes van hierdie sisteme, met name van water, lug, grond, temperatuur. Die simptome hiervan word byvoorbeeld aan sterwende vis in rivier en see, aan siek of dooie bome vanweë industrieel-besoedelde lug en so meer, herkenbaar.

Met 'n skok moes die mens die normale eers deur die abnormale ontdek. Deur sy onvermoeide tegnologiese betrokkenheid met en in die natuur, dra die mens die volle blaam vir hierdie krisis. Sy bondgenootskap met die natuur is as verraad ontmasker.

Hierdie notoriese verhouding kan dialekties aan die mens se grootheidswaan sowel as aan sy wêreldvlug toegeskrywe word. Die goddelose kontaminasie van wat mag en wat kan, vind sy tweelingbroer in 'n eksentriese antroposentrisme. Die mens verstaan nie net sy heerserposisie verkeerd nie, maar eweneens sy ingekapselwees in die natuur.

Die ekologiese krisis stel dus aan die teologie van ons dag die uitdaging om die verhouding tussen mens en nie-mens coram Deo opnuut te beskryf. Die ekologiese krisis is ook ' $n$ teologiese krisis. Dit beteken dat die teologie voor die uitdaging te staan kom om die mens se eksistensie uit die natuur, en so ook sy essensie in die natuur, te beskryf. Sowel die mens se Sosein as sy Dasein, sy bestaansin èn sy betaansgrond, moet onder die loep kom.

Die uitdaging aan die dogmatiek is dus om na 'n ontwerp wat aan die Bybelse openbaring getrou bly, te vra. Dit moet ' $n$ ontwerp wees wat die mens nie los nie, maar tesame met en midde in die totale kreatuur sien. 'n Ontologiese koherensie van alle kreature is veel meer as die belydenis van die gemeenskaplike oorsprong. Die skeppingsleer is immers creatio activa èn creatio passiva.

Daarom is die behoefte so dringend aan 'n natuurteologie. Alleen so 
kan 'n eko-etiek gefundeer word. 'n Omgewingsetiek as bloot 'n onderdeel van ' $n$ antroposentriese sosiaaletiek bevredig hoegenaamd nie. Die imperatief sonder sy onderliggende indikatief is hol. Die 'stewardship' van Hans Schulze se sosiaal-etiek skiet in die huidige situasie tekort waar die wetenskap en tegniek moontlikhede ontsluit wat vér verby die grense strek van 'n verantwoordelike huishouding soos deur die beeld van God bepaal. Ja, solank een of ander ontiese abstraksie van mens teenoor nie-mens hom iewers in die teologie skuilhou, het ons met ' $n$ dualisme te doen wat eventueel as 'n meerdere teenoor 'n mindere manifesteer. Die gevolge van hierdie sjibbolet raak vandag toenemend pynlik bekend.

En met hierdie dringende appèl op die teologie en die dogmatiek by name, is dit noodsaaklik om na die invloedryke teoloog van hierdie eeu, Karl Barth - wat vanjaar ' $n$ honderd jaar gelede gebore is - opnuut te kyk. Dit doen ons nie net omdat hy vir baie die belangrikste teoloog van die verlede is nie, maar ook omdat hy die enigste Protestantse teoloog van hierdie eeu is wat nog enigermate daarin geslaag het om die kreatuur se onderlinge koherensie ontologies te beskryf: 'Geskape syn is goeie syn' (KD III/1, 420).

\subsection{Barth se gedagteparadigma}

Waarskynlik die mees gekondenseerde uitspraak oor Barth se skeppingsleer vind ons in sy volgende stelling: 'Cott is wirklich. Seine Schöpfung ist Verwirklichung. So ist auch sein Geschöpf wirklich' (KD III/1, 401; vgl ook S.417). Dit beteken dat die skepping die produk is van die een enkele genadewerk van God waarin Hy Homself op grond van sy eie, innerlike besluit in vryheid na buite wend. Of anders gesê: vanweë God se 'Sein der Gnade' (KD II/1, $400 \mathrm{v}$ ) is Hy 'Sein in der Tat' (KD Il/1, 288 v) met sy resultaat van 'Schöpfung ist Gnade' (KD III/1, 44).

In feite beteken dit dat God se diviniteit uitloop op sy hominimiteit; sy is ekstrapoleer op sy met ons, die ontiese op die noëtiese. Kennelik gaan dit dus om God se openbaringshandeling in Jesus Christus. Dit beteken dus dat ons hier met 'n bepaalde drieslag te doen het, te wete God-aksie-mens. Erasmus van Niekerk het in 'n skitterende proefskrif oor Barth se metodologie, hierdie grondgedagte van Barth soos volg gesistematiseer (1984: 189-242): 
- God is in Homself reëel daar. Die mens word genadiglik bestem om neweskikkend voor God te staan.

- God interpreteer Homself. Die mens word genadiglik vergun om God sodanig te ken.

- God openbaar Homself. Die mens word genadiglik opgeroep om koöperatief in die skepping te wees.

Om die verhouding tussen hierdie twee pole te konsipieer, bedien Barth hom met die begrip analogie. Hierdie analogie is tegelyk ' $n$ ooreenstemming en 'n ooreenkoms. Enigeen wat hierdie sin pleonasties wil opneem, het nog nie by die kern van Barth se analogiekonsep uitgekom nie. Die verhouding tussen Christus en sy kerk vorm die grond vir die analogie tussen mens en mens en aan die ander kant is God in Homself die oerbeeld van die mens se nabeeld.

Die analogia fidei beskrywe vir Barth die faktisiteit van God. Hierdie is die a quo van die ooreenstemming tussen God en mens. Barth beroep hom hier veral op Genesis 2 se weergawe van die skepping van die mens waar die mens man en vrou geskape is. Die mens is meervoud in sy enkelvoudigheid. Die mens is dus ook ' $n$ jy, 'n objek. Hierdie analogie voer na die verbond en is dus die innerlike grond van die skepping. Christus en sy kerk is hiervan die voorbeeld. Daarom moet ons Efesiërs 5: 21-32 as die menslike pendant hiervan verstaan. Dit maak die mens die refleksie van die Goddelike prototipe. Hierdie analogie stel God dus as primêre realiteit en die mens as sekondêre realiteit. Dit is alles natuurlik net in terme van geloof deur die openbaring moontlik. Dit is geen vanselfsprekendheid nie - ons het immers met 'n analogie en nie met 'n ontologie te doen nie.

Die analogia relationis dra, in teenstelling met die vorige, nie die werklikheid oor nie, maar die moontlikheid. Barth vergelyk die teenstelling werklikheid-moontlikheid met die twee bome van die tuin: die van werklikheid (lewe) en die van moontlikheid (kennis) (KD III/1, 291-295). Hierdie is die ad quem van die ooreenkoms tussen God en mens. Die mens is dus ook 'n ek, 'n subjek. So is die mens dan die replika van die Goddelike argetipe. Barth beroep hom hier op Genesis 1 se skeppingsweergawe wat die mens in sy enkelvoud vooropstel en dus man of vrou in die oog het. Alhoewel rasionaliteit op faktisiteit volg, is dit net materieel waar. Hierdie analogie vind sy parameter tussen God se Selfinterpretasie en die menslike kennis van God. Dit is dus die mens se eerbiedige kennis van die geopenbaarde God. In die analogia fidei erken hy dus God in Christus en in die analogia relationis 
herken hy. Aangesien ons ook hier op God se openbaring aangewese is, het ons ten opsigte van hierdie twee analogieë keerkante van dieselfde muntstuk. In elke geval is dit net deur genade alleen moontlik.

In die derde instansie vind ons in die denke van Barth die sogenaamde analogia operationis. Dit is die aktualiteit wat God en mens synsmatig verbind. Synsmatig ja, want God se Selfaktualisering is reëel. Juis dit is die kern van Barth se probleem met ' $n$ analogia entis wat die syn op sigself beskou. Daarom is die groot dade van God in Christus juis die ontologiese prinsiep vir die werklikheid. Omdat die waarheid dus aksie is, is hierdie analogie die koherente krag tussen die ander analogieë. Dit is die ingrype van God wat soos ' $n$ vuishou van bo, 'n geweldige suigkrag veroorsaak en alles en almal in hierdie vakuum intrek en inhou.

Dus: Gott entspricht sich - dis waarom dit in die skepping gaan; dis die inhoud van die ganse relasie-analogie. Die analogiereeks is dus:

God $\rightarrow$ God: God/God: Jesus * Jesus: mens/mens: mens $\leftarrow$ mens.

'n Analogie wat in en deur die skepping realiseer, en in die raad van God begrond word. Binne hierdie paradigma giet Barth nou sy dogmatiek. In KD I/2 identifiseer hy ook die volgende loci:

- Godsleer

- Skeppingsleer

- Versoeningsleer
(God is die absolute subjektiwiteit)

(Absolute oorsprong van die mens)

(Die sentrum van God se absolute teenwoordigheid)

- Verlossingsleer (Die mens se absolute bestemming).

In terme van die interpretasie van bogenoemde analogiereeks, kan die afleiding dus geld dat die *, die Goddelike handeling (aktualiteit) in Christus die spilpunt tussen God en mens is. Of anders gesê: die versoeningsleer is midde in die skepping en die herskepping. Die resiprositeit van subjek en objek soos veral uit die uitverkiesingsleer duidelik blyk, word in die bostaande diagram deur die verskillende pyltjies van rigting aangedui.

Samevattend kan ons nou Barth se denkparadigma soos volg weergee (Van Niekerk 1984: 121):

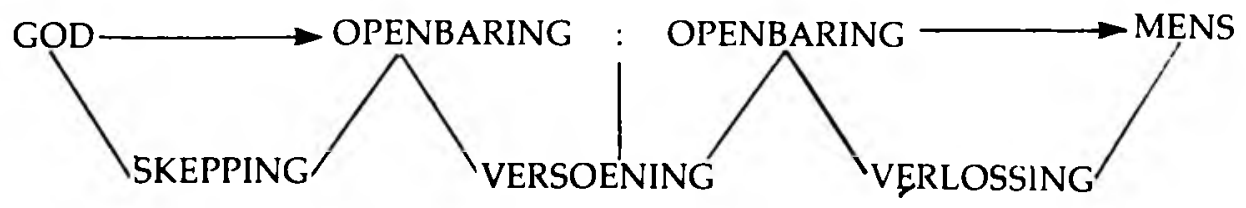




\section{DIE WERKLIKHEID VAN GOD DIE SKEPPER}

\subsection{Die Drie-enige God as die Primêre Realiteit}

Die eenheid van die Goddelike wese en die presisering daarvan as Vader, Seun en Heilige Gees begrond en bevestig die geskape eenheid en diversiteit van die verhouding skepping en verbond. Dit wil die bedoeling oordra dat God sy genade teenoor die skepping nie minder intens begrond as juis in sy eie eksistensie nie. Verbond en genade word uit die toevalligheid geneem en in die grond van alles en almal geplaas. Nou kan daar nie te min van Christus, sy kerk of sy ryk gedink word nie. Daar kan by die aanskoue van die skepping nie begrip sonder genade gevorm word nie. Hoe verbind Barth nou hierdie syn van God, sy Drie-eenheid met die skepping?

As die Vader, is God in Homself die oorsprong en die ewige bron van die ander Synswyses in die Triniteit; as Vader betuig Hy van ewigheid af Homself in sy Seun en is Hy met sy Seun van ewigheid af in die Heilige Gees die oorsprong van Homself. As die Skepper is God die begin en soewereine Heer van alle werklikheid wat van Homself te onderskei is. In hierdie verhouding tussen God tot Homself en God tot die skepping is daar 'n bepaalde pariteit. God die Vader is God die Skepper, en God die Skepper is God die Vader, maar tog kan dit alleen per appropriationem gesê word; die Bybel verbind immers die Vader en die Skepper nooit direk nie.

Wat is die implikasies vir die skeppingsleer as ons die tweede Synswyse van die Triniteit daarmee verbind? Barth antwoord dat juis in die vryheid en liefde waarin God na binne nie eensaam is nie, maar in die Seun die ewige Getuie en terselfdertyd ook die ewige Betuigde van die Vader vind, wend God Homself as Skepper na buite om ook dáár nie eensaam nie, maar in vryheid die Een wat liefhet, te wees. Barth druk dit ook heel plasties uit wanneer hy sê dat God in Homself nie stom of doof is nie, maar Hy spreek en hoor sy Woord en so wil hy ook nie buite sy ewigheid sonder eggo en gehoor, dus sonder ore en stem, in die skepping wees nie.

Die stelling kan nou gemaak word dat God geskep het met die oog op die vleesgeworde Christus. Barth stel duidelik dat Jesus alleen as die vleesgeworde Woord ter sprake gebring kan word. Hiermee het Barth die inkarnasie streng gesproke in die pre-eksistente geskiedenis ingetrek: God se ewige raad vind uitdrukking in Betlehem en Golgota (KD Il $/ 2,112$ ). Barth wil hom hiermee hoofsaaklik afwend teen enige vorm 
van metafisika. Daar durf nie in abstracto oor Jesus se preëksistensie gedink word nie. Ons het hier met 'n geheimenis te doen wat van ewigheid af in God bestaan (KD II/2, 106) en in Jesus se vleeswording sy telos vind (KD III/2,580). In Jesus het ons dus met die mees konkrete dekreet van God se raad te doen (KD II/2, 112 en IV/188). Juis dit maak 'n abstrakte spreke oor 'n Lógos asárkos so vals (KD III/1, 58). Tweedens wil Barth hom met hierdie gedagte ook afwend teen 'n soort van 'n middelwese, 'n 'derde', tussen God en die skepping (KD III/2, 580). Jesus is die ware God en mens en dit is die sin en grond van die ganse skepping. Konkreet - in die oorgee van sy eniggebore Seun - het God sy liefde vir die geskape wêreld geopenbaar. Omdat $\mathrm{Hy}$ bestaan, bestaan die skepping. En daarom is sy Middelaarskap ontologies te verstaan.

Barth se siening van tyd bring hierdie gedagte duidelik na vore. Die inkarnasie is die nunc aeternum, die Nou, waar verlede, hede en toekoms saamval. So word die agtermekaar en langsmekaar van die tyd, in Christus ' $n$ inmekaar en ' $n$ metmekaar. Hierdie is geen abstraksie van tyd nie, sê Barth, maar die genesing daarvan. Die Gekruisigde is tegelyk ook die Opgestanene.

Die Heilige Gees is ook per appropriationem Skepper. Hy is tussen die getuigende Seun en die betuigde Vader van ewigheid af die gemeenskap wat skei (Auseinander), onderskei (Zueinander) en verenig (Miteinander). Die Trinitariese wese van God is in die Heilige Gees die mees verborge sowel as die duidelikste; na binne is dit onverstaanbaar en na buite die onweerspreeklike openbaring van die eenheid en die verskeidenheid van die Vader en die Seun: in die Heilige Gees word die opdrag van die Vader en die gehoorsaamheid van die Seun gevind die Vader se welbehae en die Seun se heerlikheid. Die skeppingswerk van die Gees is dus die moontlikheid en die toestemming tussen die Vader en Seun dat eksistensie kan en mag. Hy borg die versoening met en die verlossing van God. Die Bybel verbind die Gees nooit direk met die skepping nie, maar altyd in soteriologies-eskatologiese betekenis. Die Gees van God wat oor die waters gesweef het volgens Genesis 1 vers 2, is vir Barth ook nie die Heilige Gees nie, maar die 'zur Karrikatur gewordene Gott' (KD III/1, 119). Genesis 2 vers 7 verbind egter die Gees en die skepping paradigmaties as die conditio sine qua non van die skepping. Hý is die lewe.

\subsection{Die uitverkiesing as eerste skeppingsdaad}

Naas die Drie-eenheid van God, is dit duidelik dat God se 'Sein der 
Gnade' ten opsigte van Barth se skeppingsleer, ook 'n ander dimensie impliseer, naamlik die uitverkiesing van God (KD III/2, 582).

Dit is duidelik dat Barth die uitverkiesingsleer sentraal in sy teologiese ontwerp stel: 'Die Gnadenwahl ist das ganze Evangelium, das Evangelium in nuce' (KD II/2, 13). Die vryheid, geheimenis en geregtigheid van God, vorm die hart van Barth se uitverkiesingsleer; daarom fundeer hy dit in samehang met die Godsleer en kwalifiseer dit vanuit die Christologie: dit is God se daad van genade. Dit gaan dus nie om God op sigself nie, maar God-in-Christus en ook nie om die mens op sigself nie, maar die mens-in-Christus. Daarom formuleer Barth teties: 'Jesus Christus ist der erwählende Gott' (KD II/2,111) en 'Jesus ist der erwählte Mensch' (KD II/2, 124). Die en Christō van Efesiërs 1: 4 vorm die uitgangspunt van sy argument.

Die feit dat God Jesus uit die dood opgewek het, dui daarop dat $\mathrm{Hy}$ Hom as die uitverkore mens bevestig het (KD II/2, 135). So het die versoening in Hom plaasgevind. Daarom meen Barth ook dat daar meer meriete in ' $n$ supralapsariese uitgangspunt in die hamartiologie is: 'Das Geheimnis alles Geschehens in der Welt ist die ihm ewig vorangehende Entscheidung Gottes' (KD II/2, 203).

Die verkiesing in Jesus beteken dat 'Wie er Christus wurde, so werden wir Christen' (KD II/2, 127). So is die blik van die uitverkiesingsleer direk op Christus en indirek ook op sy kerk en oordragtelik dan op die enkeling betrek. Die verkiesing van die kerk manifesteer in die verkiesing van Israel en die kerk. Dit wys oor die self heen na die gemeenskap van alle mense en word uitgedruk deur die begrippe Israel en Kerk; Jesus is die gekruisigde Messias van Israel èn die hemelse Heer van die kerk, en dus ook die opgestane Heer van die kerk èn die geopenbaarde Messias van Israel. Christus, die Uitverkorene, triomfeer oor die genadevolle einde wat Israel verwag en oor die genadevolle begin wat die kerk reeds verkondig. Daarom kan Barth ook verklaar dat Jesus die Hoof van sy kerk is, 'bevor das All war und indem das All in ihm geschaffen wurde' (KD II/2, 251). Jesus was van alle ewigheid af by God, soos ook die kreatuur en haar ganse geskiedenis in God se plan en dekreet was (KD II/2, 112). Inderdaad, die uitverkiesing is die agtergrond van die versoening en dus van die skepping (KD IV/1, 50). 


\section{DIE VERWERKLIKING VAN DIE SKEPPING}

\subsection{Skepping as weldaad}

Een vraag wat intussen dwing om beantwoord te word, is waarom God hoegenaamd ' $n$ werklikheid buite Homself gekies het? Hy eksisteer as Skepper omdat Hy dit nie te min geag het om in sy Seun self mens te word nie. Dit is ' $n$ genadige God en derhalwe 'n begenadigde skepping. 'Es darf sein' (KD III/1, 417), is Christelik gesien die mees presiese formulering van die eksistensie van God qua Skepper, die skepping en die kennis van die bestaan daarvan. Skepping is dus om deur God beaam, aangeneem, verkies te word, die tipe van Israel te wees. Bondig gestel kan mens nou sê, 'Liebe will lieben' (KD III/1, 105). Dit beteken egter nie dat $\mathrm{Hy}$ iemand of iets moes hê nie; $\mathrm{Hy}$ kon ewenwel daarsonder. Genade is die syn van die soewereine God en tegelyk ook die ontologiese grond vir die van-God-te-onderskeie werklikheid.

Die weldaad wat die skepping verwerklik het, is so om Jesus se ontwil (KD III/1, 432). Skepping en verbond word hiermee intens op mekaar betrek. Die verhouding bestaan egter uit 'n eerste en ' $n$ tweede - die skepping is die daarstelling van die ruimte waarin die geskiedenis van die genadeverbond hom afspeel (KD III/1, 46). Die waarheid van die verbond is die geheimenis van die skepping en die geheimenis van die skepping is dat die geheimenis van die verbond reeds die weldaad van die skepping omvat (KD III/1, 381). Waar skepping en verbond geskei word, verdwyn die weldaad.

Hiermee het Barth hom ook afgewend teen enige vorm van 'n Manichese dualisme. God het as Skepper ja! gesê, nie ja!-én-nee! nie (KD III/1, 378). Sy néé! het slegs weerklink oor dit wat Hy nié wil nie, wat Hy nie kies nie en daarom nie duld nie. Daarom is dit wat Hy nie verkies het nie, voorwerp van sy toorn. Juis dit maak die skepping werklik, weldaad, omdat God dit wou en dit dus God se ja! wegdra.

Die feit dat God die skepping met sy ja! verwerklik het, stel nie net die feit daarvan nie, maar ook die kwaliteit: die skepping is nie sleg nie, maar goed, baie goed (Genesis 1: 31). Beter as die skepping kan net die doel van die verbond wees (KD III/1, 418). Barth meen dat die skepping goed is, reg is - soos hy meen die betrokke teks verstaan behoort te word - vir die doelstelling en die voltrekking van die verbond van God met die mens (KD III/1, 240). Die skepping is geregverdig omdat dit die struktuur bied waarbinne die mens die geskikte voorwerp is vir die Goddelike werk wat in Christus begin, verloop en 
eindig. Daar klink dus, naas God se ja! ook 'n optimistiese ja! vanuit die skepping self op! Dit is die lof en dank aan die Skepper vir die orde, waarheid en doelmatigheid van die skepping. Vergelyk hiervoor die accensae lampades in paragraaf 69 van die Kirchliche Dogmatik. Tog is dit geen inherente kwalifikasie van die skepping self nie. (KD III/1, 425). God is met ander woorde dus nie identies aan sy ja! nie. God het immers ook nog 'n nee!; by sy genade is daar ook die gerig. God gaan egter net so min in sy nee! op as in sy ja! Dit is ewe onmoontlik om vanaf die glans van die skepping as vanaf die skadu daarvan by God uit te kom (KD III/1, 428). 'n Negatiewe natuurlike teologie is ook onmoontlik. Hiermee wil Barth sê dat die goedheid van die skepping nie eers ter sprake kom daar waar sy eie immanente goedheid as skyn ontmasker word nie - die geregtigheid van die skepping begin nie eers by sy grense nie. Die negatiewe oordeel het immers ook reg en grond oor die skepping. Of anders uitgedruk: die skadu van die skepping is nie niks nie, dit grens net daaraan (KD III/1, 430). Dit bly egter goed omdat God die grond van albei pole is; Hy het die skepping reg verklaar juis in hierdie polariteit. Trouens, Hy het dit aldus in sy Seun aangeneem nog voor die wêreld geskape is (KD III/1, 436)! Juis dit is die genade van die verwerkliking van die skepping, naamlik dat God bereid is om ons te dra 'was wir sind und wie wir sind' (KD III/1, 438). Sy verbond is daarop gerig om hierdie spanning te oorkom.

\subsection{Skeppingsleer is geloofsleer}

Wanneer Barth oor die werklikheid van die skepping praat, doen hy dit nie $a$ posteriories deur by die skepping self te begin nie, maar wel $a$ priories deur die werklikheid van die skepping as die resultaat van die werklikheid van God te sien. Die werklikheid kan nie deur die bewussyn van die mens, hetsy selfbewussyn, wêreldbewussyn of religieuse bewussyn, begrond word nie. Die mens weet nie onmiddellik van sy eie of ' $n$ ander werklikheid af nie. Wat hy uit homself weet, is bloot skyn en 'n vermoede.

Hieruit is dit nou duidelik dat ons as 't ware van buite ons kennis oor die skepping ontvang. Wat die grond en die waarheid van alles is, moet aan ons geopenbaar word. So moet ons eers aan God en sy eksistensie gló voordat ons van ons eie, en die wêreld se bestaan af weet. Hiermee vind die ontiese begronding sy voorwaarde in die noëtiese. Die kennis van die Goddelike eksistensie is dus geheel en al eggo 
èn antwoord op dit wat die Skepper aan sy skepsel geopenbaar het. Dit is kennis wat in erkenning begrond is - onder die wet van geloof en gehoorsaamheid. Die dialektiek van die self-en wêreldbewussyn het hieraan geen deel nie.

Dit dwing ons nou om by die menslike beslissing vir Christus uit te kom (KD I/1, 252). Die uitgangspunt vir Barth is dat die eerste artikel van die Apostoliese Geloofsbelydenis nooit sonder die tweede en derde durf verstaan word nie. Die mens beskik oor 'kein Organ und keine Fähigkeit', om hierdie kennis uit homself te bekom nie. Hy kan die Goddelike getuienis slegs ontvang en uitlewe.

Drie redes kan nou aangevoer word waarom hierdie eerste artikel vir Barth 'n suiwer geloofsartikel is en nie 'n articulus mixtus nie. Eerstens is dit nie selfevident dat daar ' $n$ ander werklikheid met ' $n$ 'eigene Wesen' buiten God bestaan nie. Toegespits geformuleer: dit kan met ander woorde nie bewys word dat God móés skep nie. So kan nòg bewys word dat God alleen bestaan, nòg dat die wêreld nie eksisteer nie. Dit is 'n Goddelike openbaring dat ons weet dat God die wêreld fakties geskape het. Tweedens beteken dit dat die wêreld kontingent is. Dit behoort nie aan homself nie en kan ook nie oor homself beskik nie. God is die sin en krag, ja die Heer daarvan. Derdens beteken dit dat die Bybel alleen outoritêr oor die skepping kan spreek. Barth bedoel hiermee nie dat bloot na die beginhoofstukke van Genesis gekyk moet word nie. Die Bybel moet vanuit sy sentrum, Jesus Christus, verstaan word; en $\mathrm{Hy}$ is nie maar net een van baie getuienisse in die Skrif nie. ('n Feit wat klaarblyklik deur E Brunner 1952: 7 in sy kritiek teen Barth se skeppingsleer totaal misgekyk is.) In Hom het God self die verhouding tussen Skepper en skepping bepaal en bestem. Daarom sê Barth: 'Die ganze Bibel redet vorbildlich, weissagend von ihm, von Jesus Christus, wenn sie von der Schöpfung, vom Schöpfer und vom Geschöpf redet' (KD III/1, 24). Wat in vooruitskoue van Hom gesê word, kan nie anders as om verstaan te word in terugskoue vanaf Hom nie.

In Jesus is dan die 'bewys' dat God nie alleen is nie, maar dat daar 'n wêreldruimte is waarin Hy oor 'n skepsel buite Homself - die mens Heer is. Jesus het die vlees aangeneem en God só Een gemaak wat in verhouding met die mens te staan gekom het.

Soos daar dus nou 'n werklikheid buite God vanweë Jesus is, is die mens ook vanweë Hom bewus van God se werklikheid. Hy maak die mens bewus dat hy nie in homself begrond of rustend is nie. As gevolg van die feit dat die mens die skepsel is, is dit hý wat God behoef en nie andersom nie. Dit beteken dat dankbaarheid die wese van sy syn vorm. 
Met ander woorde, waar ons gesien het dat die geskape werklikheid sy grond in die verkiesing van Jesus vind, vind dit die kennis daarvan in die openbaring van Jesus Christus. Die ontiese sowel as die noëtiese grond sentreer in Jesus Christus; eersgenoemde is die grond van laasgenoemde en laasgenoemde is die kennisweg tot eersgenoemde.

Dit gaan hier dus om 'n credo, ut intelligam - ek glo in Jesus Christus sy eniggebore Seun, ons Here en daarom ken ek God die Vader, die Almagtige, Skepper van hemel en aarde. Glo ek hier in die tweede artikel, weet en verstaan ek in die eerste artikel. Hierdie is die 'Hauptsatz des christlichen Bekenntnisses' (KD III/1, 19), die fides quae creditur.

Vanweë hierdie feit kan Barth ook die teologie en die natuurwetenskap se grense prinsipieel onderskei (KD III/1, Voorwoord). Die Christologiese interpretasie van die hemel en aarde sien Barth in dit wat nié gesê word nie; dit waaróm dit eintlik gaan, word hiermee verswyg; dit wat nòg hemel nòg aarde is, nòg engel nòg dier, is die fokus van die skepping, naamlik die mens (KD III/1, 18). Hierdie antroposentrisme van die Bybel sien Barth onder andere in Psalm 104: 23, Psalm 139 en Job 38. Aangesien 'n ontologie van hemel en aarde vir Barth onmoontlik is, moet dit altyd deur (heils-)gekiedenis gekwalifiseer word. So spel die ganse skepping vir Barth duidelik uit: Ecce Homo! Hier is die Menseseun midde in die kosmos - bo die aarde en onder die hemel.

Samevattend kan ons sê dat ons hier met 'n stellingname en 'n beslissing te doen het. Geloof in Christus is erns maak met God as Skepper; dis ' $n$ inagneming van God se albeskikkingsmag in die verlede, hede en toekoms. Die werklikheid is die skouterrein, werktuig en voorwerp van hierdie dade wat in Jesus Christus, Heer van die kerk en Messias van Israel, saamgetrek en geopenbaar is. Dan word dit 'n lewe in die teenwoordigheid van die Skepper. Dit is die kennis en belewenis van die welwillendheid van God. En dit voer na die bestemming in Jesus Christus wat die ware grond en sin van die mens is; dan gaan dit nie net om wat God is nie, maar ook om wat God vir ons gedoen het.

\section{DIE VERBOND AS DIE DOEL VAN DIE SKEPPING}

\subsection{Die Mens Jesus as dié Verbondsgenoot}

Barth vertolk die creatio passiva streng antroposentries: 'Die theologi- 
sche Lehre vom Geschöpf ist aber praktisch Anthropologie: die Lehre vom Menschen' (KD III/2, 2). Dit is met uitsondering dat Barth met 'das Geschöpf' nie die méns bedoel nie. Daarom is dit vir hom moontlik om die skepping te bestempel as die daarstelling van die ruimte vir die geskiedenis van die genadeverbond. Sy behandeling van die skeppingsberigte in Genesis toon duidelik dat dit vir hom om die méns gaan en dat die mens die voorwerp van God se genade is. Die skeppingsleer by Barth kan dus nie beoordeel word sonder sy antropologie èn soteriologie nie. Natuurlik is die antropologie nie identies aan die Christologie nie. Die een mens, Jesus van Nasaret, het geen sonde gehad nie; daarom kan daar geen sprake van summiere identifikasie tussen Jesus en die ander mense wees nie. Die antropologie - of ook die ontologie van die mens - is dus vir Barth teologiese antropologie. Wie méns wil sê, moet dus eers Gód sê.

Ons kan die antropologie van Barth in twee kategorieë plaas: die menslike betaansgrond en die menslike bestaansin, sy Dasein en sy Sosein. Ons sou hierdie onderskeid ook kon noem die eksterne grond en die interne grond van die mens (KD III/2, 243). Hierdie dubbele perspektief verwoord Barth as volg: ' $\mathrm{Er}$ ist sich selber da drunten, ob er es weisz oder nicht, Zeichen dessen, was er von oben, von Gott her gesehen, wirklich ist' (KD III/2, 247). Vanweë Barth se Christologiese benadering in die antropologie, het ons ook hier nie met twee verskillende sake te doen nie, maar keerkante van dieselfde muntstuk. Tussen hierdie kante bestaan daar ' $n$ inherente verhouding, maar geen identifikasie nie: Die verhouding hiertussen word ook met begrippe soos Entsprechung, Aehnlichkeit en Analogie aangedui. Aangesien die geskape menslike natuur van die mens vir Barth sy dualiteit, sy siel en liggaam en sy tyd is, val dit buite die bestek van die onmiddellike oogmerk om na die mens 'als diesen Bundesgenossen ... dasz und wie er von Gott geschaffen ist' (KD III/2, 243), te vra. Die laasgenoemde perspektief egter, die mens 'als Gottes Geschöpf ... wozu ihn Gott geschaffen hat' (KD III/2, 243), werp egter lig op ons problematiek.

Jesus Christus is die kenprinsipe in Barth se skeppingsleer, juis omdat hy Hom as synsprinsipe sien. Die mens is nie net noëties nie, maar ook - en dit by uitstek - onties op God gerig. Die syn van die mens is vir Barth van huis uit syn met God, omdat God met die oog op die verbond die mens geskep en bestem het. Dit is duidelik dat ons hier met mens die werklike mens Jesus Christus, bedoel.

Wat is nou die ontologiese bestemming van die mens? Barth antwoord: 'Er schuf ihn zu seinem Bundesgenossen' (KD III/2, 242). 
Die werklike mens leef dus nie sonder God nie. Hy leef en werk in die verbond - hy dank God vir sy genade en leef in verantwoordelikheid. Hieruit is dit ook duidelik waarom Barth sê dat God die mens tót en nie ás verbondsgenoot geskape het nie. Die mens is dus nie van nature bondgenoot nie. Dit is juis sy bestemming waaronder hy geskape is en eksisteer. ' $n$ Direkte identifikasie tussen verlossing en skepping wil Barth immers nie hê nie. Hy verklaar immers duidelik, 'Die Schöpfung ist nicht selbst der Bund' (KD III/1, 106). 'n Stelling wat die vermoede van 'n apokatástasis in Barth se uitverkiesingsleer dan ook besweer, is die volgende: 'Die Existenz und das Wesen des Geliebten ist ja nicht identisch mit seinem Geliebtwerden' (KD III/1, 106). Skepping is nou gelyk aan die 'Existenz und das Wesen des Geliebten' en die verbond of versoening aan die 'Geliebtwerden'. Die konstitutiewe is nou dat Barth nie sê dat die eksistensie en wese van die ménse nie identies is aan sy geliefd-wordende nie, maar dat sy geliefde nie daarmee identies is nie. Die geskape mens is die geliefde en so iemand is nie noodwendig die een wat onder die aktiewe liefde is nie. Tussen voorwerp en gebeure is ' $n$ onderskeid. So vorm die voorwerp van die liefde die eksterne grond (Gen 1) en die gebeure van die liefde (Gen 2) die interne grond van die voorwerp van die liefde! Die mens as voorwerp van God se liefde is algemeen, maar die mens as gebeure van God se liefde is partikulier. Laasgenoemde is nie ' $n$ eienskap van eersgenoemde nie, maar kom dit toe - dit is sy bestemming. So leef die bondgenoot uit God en tot God. Die werklike mens leef van God af en ook na Hom toe en word deur Hom tegemoetgekom.

\subsection{Versoening as vervulling van die verbond}

'Die Versöhnung ... ist die Erfüllung des Bundes zwischen Gott und Mensch' (KD IV/1, 22). Hierdie vervulde verbond is die hart van die Christelike boodskap; die skepping en die eskatologie is hierby net periferies. Die versoening in Jesus Christus is die gevolg van die verbondsgemeenskap soos God dit tussen Hom en die mens bedoel het om te wees (KD IV/1,37). Versoening geskied nie vanweë die skepping nie, maar wel vanweë die verbond. Of anders uitgedruk, die teleologiese gesigspunt van die skepping is die verbond en nie die versoening nie. Dit beteken dat die versoening sy aanleiding in die sonde vind, maar nie sy grond nie. Versoening is dus geen toevallige werk nie, maar gegrond in God se wese. Aangesien die sonde niks meer as 'n 
episode is nie (KD IV/1,37), is dit ook nie kragtig genoeg om God tot aksie te provokeer nie; dit dien niks meer nie as om die aanleiding te verskaf dat die trou van God as Verbondsgod manifesteer. Die versoening toon dus die sonde as God se nee! en bestaan links van God (KD IV/1,49). Die versoening toon hierdie ónwese van die sonde aan. 'n Onwese wat God reeds van die begin af verwerp het.

Anders as die sonde, is die positiewe ja! van God teenoor die mens 'Ich will euer Gott Sein' (KD IV/1, 39) - geen insidentele episode nie, maar die noodwendige gebeure. Dit lê ten grondslag van alles. In Jesus Christus is God die 'Ek sal vir julle 'n God wees' en word dit duidelik dat die uitverkiesing in God se raad die agtergrond van sowel die skepping as die versoening vorm. In Hom word die verbondsbedoeling dus realiteit. Die tussenfase van die sonde onderstreep bloot die genade van God (KD IV/1, 74). Die oorwinning oor die sonde in die versoening is dus voltooiing van die oorspronklike bedoeling van die skepping en dus van die verbond (KD IV $/ 1,50$ ).

Daarom is die inkarnasie geen status quo ante-herstel nie; ook nie 'n restitutio ad integrum nie. Dit is die realisering van die volheid van die esgaton (KD IV/1, 12). In ons plek het Jesus voor God te staan gekom en deur Hom het ook ons nou partisipasie aan die syn van God (KD IV/1, 14). Dit is die eenduidige betekenis van die inkarnasie - 'Gott mit uns' - en dit is die Christelike geloof en hoop.

Tog kan die mens nie hierop aanspraak maak nie. Die verbond is immers genade en die versoening die vryheid van God. Die syn van God is genade en daarom ook die ontiese verhouding. Ook kennis hiervan is genade. In Jesus Christus is dit geopenbaar omdat dit in Hom begrond is. En daarom is die verbond genade.

Met die versoening wat dus onder die teken van die belofte staan, is dit nodig om die universele vervulling in en deur Jesus te besef. Daarom kan Barth sê dat die wêreld ter wille van Jesus geskep is (KD IV/1, 53). Hierdie werk gaan die skepping vooraf en begrond en bestem dit dus; die skepping is alleen die daarstelling van die arena waarbinne hierdie verbondsgeskiedenis hom afspeel en in die versoening in Jesus tot rus kom. Barth sê dus: 'Der Bund ist nicht ebenso alt wie die Schöpfung, er ist älter als diese' (Grundrisz, 81).

\section{KRITIESE WAARDERING}

Die bydrae wat Barth tot die verstaan van die skepping gemaak het, is geweldig. Die skeppingsproduk is vir hom goed, baie goed, ontologies 
goed. Dit is alleen moontlik omdat God goed is. In Homself as die Drieenige God is $\mathrm{Hy}$ in verhouding van genade, en in hierdie syn van genade grond die optrede en aksie van God wat self ook niks anders as genade is nie. Aangesien die skepping sy herkoms in die syn van God vind, moet die bestemming daarvan ook daarin lê. Met ander woorde, die skepping is goed omdat dit sowel uit God as tot God is. Dit is goed nie net omdat dit God se sprekende ja! is nie, maar ook omdat dit die antwoordende ja! van die mens moet laat resoneer. Sonder hierdie dialektiek is die skepping nie net onvoltooid nie, maar ook boos, die skepping kan 'nicht "bar" existiert' nie (KD III/1, 418). Die regverdiging kan nie anders as om die verwerkliking van die skepping te kompleteer nie. Dit beteken dat Jesus Christus die spilpunt van die ganse werklikheid is; die begin, die verloop en die doel van die skepping wentel om Hom. In en deur Hom vind ons die sin van die ganse skepping; Immanuel. Dit is God vir die mens en die mens vir God. En dit is Jesus ontologies reeds van altyd af. Dit is God se ewige oogmerk. Hierdeur het Barth ' $n$ ontologiese voorrang aan die Immanuel bó die skepping gegee en word die skeppingsgeloof 'n ekstrapolasie van die heilsgeloof. Die geykte theologóumenon van skepping-verbond-geskiedenis word nou prinsipieel omgeruil na verbond-skepping-geskiedenis. Vir ons tema het dit geweldige betekenis: Barth kan sowel die menslike as die nie-menslike kreatuur ontologies op mekaar betrek. Dit word nie anders verstaan as die buitekant en die binnekant van een en dieselfde saak nie. Die skepping as esse verum et bonum is in Christus konkreet en reëel.

Die vraag is egter nou of Barth nie ook 'n prys wat te hoog is, hiervoor moes betaal nie? Bly in die slag nie dalk dit wat die teologie nié kan bekostig nie?

Alhoewel Barth toegee dat daar meer meriete in 'n supralapsariese as in ' $n$ infralapsariese redenasie is, wys hy in sy uitverkiesingsleer nietemin albei posisies af. Die vraag wat ons hier wil beredeneer, is of Barth se teologie hom wel toelaat om enige vorm van ekstreme supralapsarisme af te wys? Sou die vraag ontkennend beantwoord word, beteken dit dat Barth hom aan ' $n$ bepaalde vorm van doketisme skuldig maak deurdat die versoende skepping eers die werklike en volle skepping is en dat die aanvanklike skepping onaf en dus onwerklik is; die verskil hiertussen is die verskil tussen skyn en syn. Omdat die aanvanklike skepping versoen móét word, beteken dit dat die sonde eerder noodlot as skuld is, en dat die mensegeskiedenis hier op aarde dus sy erns verloor deurdat daar nouliks nog van 'n sondeval en 'n historiese 
versoening gepraat kan word; die skepping word dan die spieël van 'n monistiese Godsproses. Alles is reeds vooraf bestem en wat nou in die skepping gebeur, is die afspeel van hierdie reeds geredigeerde drama. Die aanvanklike skepping vervlugtig omdat dit slegs voorafskaduwing van die versoende skepping is en is dus self kwalik meer as ' $n$ skaduwee.

Die kruks in die argument of Barth voorwaardelik of dan volstrek supralapsaries dink, hang af van die feit hoe hy sonde en versoening beskou. Die kernpunt is dus of die sonde nie méér is as net' $n$ 'kontingente episode' in die verbondsgeskiedenis nie; met ander woorde, moes die sonde nie noodwendig plaasvind nie? Betrek mens die probleem vanuit die versoening, kan mens vra of die versoening nie dalk geskied het vanweë die skepping en nie vanweë die sonde nie? Kortom, is die onderskeid tussen God se ja! en sy nee! dalk nie tog só pertinent nie?

Gaan Barth egter nie verder met hierdie supralapsariese beskouing van hom nie? Is die verhouding tussen skepping en versoening onderliggend in sy denke, nie eerder teleologies as analogies nie? Het God geskep nie net met die wete dat $\mathrm{Hy}$ sou moes versoen nie, maar ook met die bedoeling? Dit lyk tog of ons hierdie vrae sal moet beaam. Barth hanteer die analogie tussen die skepping en die versoening sodanig dat dit onmiskenbaar op 'n teleologie dui. Die skepping van die man en sy vrou dui nie net op die verhouding tussen Christus en sy kerk nie, maar mik ook op die verlossing van die kerk deur Christus! Dit beteken dan dat die sonde geensins kontingent is nie, maar dat die versoening sy aanleiding reeds voor en met die skepping vind. Die wyse van die skepping van die vrou uit haar man, dra intrinsiek reeds die kiemsel van die sonde en illustreer bogenoemde stelling afdoende:

Warum muszte die Frau vom Manne genommen werden, Gebein von seinem Gebein sein und Fleisch vom seinem Fleisch? nämlich 'gebaut' aus seiner Rippe? D a r u m, weil der Tod Jesu seine Dahingabe für seine Gemeinde sein, weil ihre Versöhnung eine Vertauschung zwischen göttlicher Herrlichkeit und menschlichem Elend sein sollte (KD III/1, 368).

Die noodwendige parallel kom tot uitdrukking in die feit dat Barth die woord daarom gebruik en dit boonop litografies aksentueer. Die skepping is dus geen illustrasie-materiaal vir die versoening nie, maar die bewýs daarvan! Nie die teken word aan ons voorgehou nie, maar die wese self! En hierdie is een van etlike ander voorbeelde. Mens sal die 
afleiding moet maak dat die mens gepredestineerd is om te sondig; dat sy samestelling en oorsprong hom daartoe dwing!

Hierdeur verkry die skepping nou duidelik 'n voorlopige en aanwysende betekenis. Die skepping het plaasgevind in die teken van die verlossing. Dit is dus significatio redemptionis. Meer as die sakrament van die versoening kan die skepping nie wees nie. Die esse van die skepping het Barth vervang met die significare van die versoening (Prenter 1977: 17). Per se moet die skepping versoen word, anders is dit onwerklik: 'Die Person Jesu Christi ist der Erweis, dasz das Geschöpf ist' (KD III/1, 26). En soos Barth in die ontiese sfeer die esse met die significare omruil, wissel hy in die noëtiese sfeer die intelligere met die credere. Dit beteken ongeveer dat Barth gló waar ander mense weet en dat hy wéét waar ander glo! So glo hy dat die skepping werklik is: 'Ist die Welt nicht von Gott geschaffen, so ist sie nicht. Erkennen wir sie nicht als von Gott geschaffen, so erkennen wir nicht, dasz sie ist' (KD III 1,5$)$. En wéét Barth wat die geheimenis van God is; herken hy waar ander net kan erken:

Ja mehr Zusammenhang blosz und nominal verstanden, je mehr die Einsicht in die innere Einheit der Werke Gottes verdrängt würde durch die Vorstellung eines stufenmäszigen Nacheinander oder Nebeneinander zweier an sich getrennter Bereiche, desto mehr müszte auch der Satz, dasz Gottes Schöpfung Wohltat ist, aüszerlich und nominal, zu einer bloszen Behauptung werden .... (KD III/1, 381).

Barth praat hier van die 'insig' in die innerlike werk van God, hy 'sien' die na- en langsmekaar van skepping en verbond as sou hy oor objektiewe aangeleenthede praat. Die objektiwiteit van die skepping en verbond wat in God is, word kennis van die mens. God se geheimenis het voorhande geword! Mens sou kon vra of Barth nie met hierdie epistemologiese resultaat van hom die grense wat hy self tussen die teologie en die natuurwetenskap neergelê het, oortree nie. Met hierdie wisseling van rede en geloof, het Barth sowel die opset as die struktuur van die Apostoliese Geloofsbelydenis verander. Dit is immers nie net uit stilistiese gronde nie dat die Belydenis nie minder as drie keer met credo begin en dan boonop die Vader voor die Seun noem nie. Die analogie tussen God en Jesus as die Gekruisigde en Opgestanene, dreig nou om 'n bo-tydelike prinsipe te word wat die ganse wêreldgeskiedenis ontologies-analogies verklaar. 
Dit kom voor of Barth bedoel dat die skepping nie soos Genesis 2: 2 sê dat dit op die sewende dag reeds voltooi was nie, maar dat dit éérs met die inkarnasie van Christus voltooi is. Met hierdie siening van hom waar die skepping eers in die inkarnasie sy voltooiing vind, bevind Barth hom egter in ' $n$ onbenydenswaardige dilemma. Enersyds is dit vir hom 'n uitgemaakte saak dat Christus van alle ewigheid af die Lógos ensárkos is; die skepping is dus in dié sin reeds op die sewende dag voltooi omdat die preëksistente Woord as Skeppingsmiddelaar juis die vleesgeworde Woord is; Christus is nog altyd in die vlees. Maar dit is juis die dilemma: beteken dit nie dat die belang van die historiese inkarnasie sekondêr word nie? Andersyds kan die historiese inkarnasie so sentraal in sy redenasie gestel word, dat die geskiedenis daarvóór sekondêr word. Of die historiese Jesus òf die skepping voor die begin van ons jaartelling is skyn.

Barth wil natuurlik nie een van hierdie twee randstene raak nie, met die gevolg dat 'n onbegrypbare 'tussending' in sy teologie te voorskyn gekom het. Van Genesis 1: 2 sê Barth dat die chaos in sy absurde bestaansvorm en -wyse, tog 'werklik' is, al is dit téén God se wil. Tog kan Barth ook nie sonder sy aanhalingstekens wegkom nie (KD III/1, $430)$ !

'n Aantal vrae spruit nou hieruit voort: Wat vir 'n wêreld is dit wat bestaan tussen die voorhistoriese skepping en die historiese versoening? Wat vir 'n volkegeskiedenis was dit wat chaoties buite Israel bestaan het? En wat vir ' $n$ menswees is dit wat ontologies buite Christus is (KD III/2, 162)? En dan kan mens ook vra, wat vir ' $n$ Lógos ensárkos was dit wat Skeppingsmiddelaar was? Wat vir menslike vlees is dit wat nie gebore is nie?

Is die skepping ná die historiese kruisiging en opstanding anders as daarvoor? Bestaan hierdie 'tussendinge' net voor Jesus aarde toe gekom het? Nee. Die feit dat Barth die vleeswording in 'n sekere sin onthistoriseer, beteken dat die skepping prinsipieel nie anders vóór hierdie dag en datum is as daarná nie. Tensy dat Barth 'n alversoening verkondig, bly hierdie soort 'tussending' steeds voortbestaan. En dit wil hy nie.

Ten slotte dus - vanweë Barth se radikale supralapsarisme - verval hierdie wêreld met sy geskiedenis, volgens sy skeppingsleer, in skyn; 'n prys wat beslis nie bekostig kan word nie. In hierdie wêreld het ons nie sélf daarmee te doen nie, maar met die teken van iets of liewer lemand Anders. ' $n$ Ontologie van die nie-menslike kreatuur is vir Barth onmoontlik. In concreto kan die wêreld nie bestaan nie, en en Christō is 
dit niks anders as 'n sakrament van die Immanuel nie. Ja, die kosmetiese en dekoratiewe funksie wat Barth die nie-menslike kreatuur in hierdie verbondsgeskiedenis tussen God en mens toesê, verword tot ' $n$ spieëlbeeld van 'n vooraf-uitgewerkte drama van God mét die mens. Die antroposentristiese (sic) verstaan van die werklikheid waar die niemenslike kreatuur tot diens van die menslike kreatuur staan, soos ongeveer die liggaam tot die gees (KD III/2, 489), verword tot 'n Christomonistiese synsprinsipe waar hierdie wêreld tot diens van die eintlike wêreld staan, soos ongeveer die sakramente tot die kruisgebeure. Skeppingsgeloof is vir Barth ' $n$ allegorie (KD III/1, 49). Dit is vir Barth net maar' $n$ voortsetting van die eintlike teologiese vraag: Wie is God? Derhalwe ontkom sy skeppingsleer nie aan die klag van 'n geweldige reduksie nie. En 'n teologies-gefundeerde eko-etiek wag dus steeds om begrond te word.

Kom ons sê dit maar reguit: Barth se ontologiese verbondsbeginsel vorm 'n kanon ágter die kanon. Hoe anders kan ons dit verklaar dat hy teen sy eie pretensie in, nie net van God as ' $n$ Hy kan praat nie, maar ook as 'n Ek, dat hy van die derde persoon van God selfs kan oorgaan na die eerste persoon? Sy fantastiese vermoë van oorspronklikheid en konsekwentheid vorm die eintlike vertrekpunt in sy Skrif- en dogmatiekomgang. Ten diepste het ons hier met 'n filosofie en dus met 'n metafisika, te doen (vgl Van Huyssteen 1986: 31)!

\section{4. 'N WEG NA 'N THEOLOGIA NATURAE}

As ons bely dat God die Skepper van hemel en aarde is, benodig ons ' $n$ verstaan van die werklikheid wat God, mens en natuur in die geheel omvat. Die een is nie sonder die ander te verstaan nie (Pannenberg 1970: 35). Die teologie benodig dus nie 'n dualistiese (dis teologies arm en ekologies niksseggend) en ook nie 'n monistiese verstaan nie (dis teologies vals en ekologies niksseggend), maar wel 'n globale verstaan van die werklikheid.

Dit sal beteken dat Barth se indifferente houding teenoor die natuurwetenskap (KD III/1, Voorwoord), plek sal moet maak vir 'n sinergistiese werklikheidsomgang. (Alhoewel Barth self hom nie juis altyd aan sy eie standpunt in hierdie verband gesteur het nie! Vergelyk KD III/2, 18, 19-105, 188 v, 238 vv; III/3, 145, 274 v, 290 et passim.)

'n Statiese skeppingsbegrip sal ook geostraseer moet word. Die teologie sal weer na die ewolusie van die skepping moet gaan kyk, net soos dit na die skepping van ewolusie moet kyk. Interessant is dat Barth 
vanaf $\mathrm{KD}$ III/1 na KD III/2 die skepping al hoe meer soepel beskryf en selfs die moontlikheid vir 'n eerste en 'n tweede skepping ooplaat (KD III/2, 184). Tyd moet vloei. 'n Totaal onontginde perspektief vir 'n ewolusionêre verstaan van die skepping is die teologiese interpretasie van die 'En dit was so' of die 'So het dit gebeur' wat refreinagtig in die priesterlike weergawe van die skeppingsgebeure voorkom. Hierdie formule sluit nie 'n gedagte af nie, maar lui dit in! Dit is oop na voor (vgl Rig 6: 38, 2 Kon 7: 20 en 15: 12)! Waarom staan hierdie formule met die skepping van mens en dier eers aan die einde van die gebeure op die sesde dag? Onteenseglik roep hierdie formule na vervulling.

Die Christologiese verstaan van die antropologie moet deur ' $n$ Pneumatologiese ontologie gekompleteer word. Christus het mens geword, maar ewenwel ook materie! Dit is wat kreatuur ook beteken! Die kosmiese Christus vra verdere studie. Daarom moet die gees-liggaam-digotomie vir eens en vir altyd besweer word. Barth se siening dat die protesterende liggaam maar net met 'n pilletjie weer diensbaar gemaak kan word, misken hierdie eenheid. Die subjek-wees van die mens moet in ' $n$ resiproke verhouding tot sy objek-wees staan.

Sodanige solidariteit verhoed 'n grootheidswaan of wêreldvlug en lei tot die besef dat 'wat jy saai, kom nie tot lewe tensy dit eers sterwe nie'. Die gedagte van Psalm 90 dat wysheid ook in 'n sterwensbewussyn geleë is, moet weer praktiese geloof word. Offervaardigheid en lydingskap vervang dan die Franciskaanse askese. Dan moet ons opnuut weer van die ekstrapolasie van die hoop uit die lyding bewus word. Ekologies gesproke, is die betekenis van die sug van die niemenslike kreatuur soos in Romeine 8: 18-25 uitgespel, lank nog nie uitgeput nie. Die eschatologia crucis spel die hoop prolepties-dialekties midde in die puinhoop van die ekologiese krisis uit.

Verantwoordelikheid van en teenoor die kreatuur moet nie net bloot 'n eis of appèl wees nie, maar die intrinsieke noodwendigheid van 'n dogmatiek wat God, mens en nie-mens só met mekaar verbind dat uitbuiting onmoontlik is. Nie die 'terugkeer na die natuur' word bepleit nie, maar die vooruitgrype van die natuur self na die heil, volheid en voleinding.

Maar dan moet dit alles binne ' $n$ historiese visie op die openbaring geskied. Anders is dit nie teologie nie.

\section{Literatuurverwysings}

BARTH, K 1960. Die Lehre vom Wort Gottes: Prolegomena zur kirchlichen Dogmatik. Zweiter Halbband, in Die Kirchliche Dogmatik 1/2. 5 Aufl. Zurich-Zollikon: Evangelischer Verlag. 
BARTH, K 1958. Die Lehre von Gott. Erster Teil, in Die Kirchliche Dogmatik II, 1. ZürichZollikon: Evangelischer Verlag.

BARTH, K 1959. Die Lehre von Gott. Zweiter Teil, in Die Kirchliche Dogmatik II, 2. 4. Aufl. Zürich-Zollikon: Evangelischer Verlag.

BARTH, K 1970. Die Lehre von der Schöpfung. Erster Teil, in Die Kirchliche Dogmatik III, 1. 4. Aufl. Zürich: EVZ.

BARTH, K 1979. Die Lehre von der Schöpfung. Zweiter Teil, in Die Kirchliche Dogmatik III, 2. 4. Aufl. Zürich: EVZ.

BARTH, K 1960. Die Lehre von der Versöhnung. Erster Teil, in Die Kirchliche Dogmatik IV, 1. 2. Aufl. Zürich-Zollikon: Evangelischer Verlag.

BARTH, K 1959. Die Lehre von der Versöhnung. Dritter Teil, in Die Kirchliche Dogmatik IV, 3. Zürich-Zollikon: Evangelischer Verlag.

BARTH, K 1947. Dogmatik im Grundrisz im Anschlusz an das apostolische Glaubensbekenntnis. Stuttgart: Kohlhammer. (Siteer as Grundrisz).

BRUNNER, E 1952. The Christian doctrine of creation and redemption. Philadelphia: Westminister.

PANNENBERG, W 1970. Kontingenz und Naturgesetz, in Müller, AMK (Hrsg), Erwägungen zu einer Theologie der Natur, 33-80.

PRENTER, R 1977. Die Einheit von Schöpfung und Erlösung: Zur Schöpfungslehre Karl Barths, in Theologie und Gottesdienst - Gesammelte Aufsätze, 7-28. Göttingen: Vandenhoeck.

SCHULZE, H 1979. Theologische Sozialethik. Gütersloh: Gerd Mohn.

VAN HUYSSTEEN, JWV 1986. Teologie as kritiese geloofsverantwoording: Teorievorming in die sistematiese teologie. Pretoria: RGN. (RGN-studies in navorsingsmetodologie 2.)

VAN NIEKERK, E 1984. Methodological aspects in Karl Barth's Church Dogmatics. D Thproefskrif, Universiteit van Suid-Afrika. 